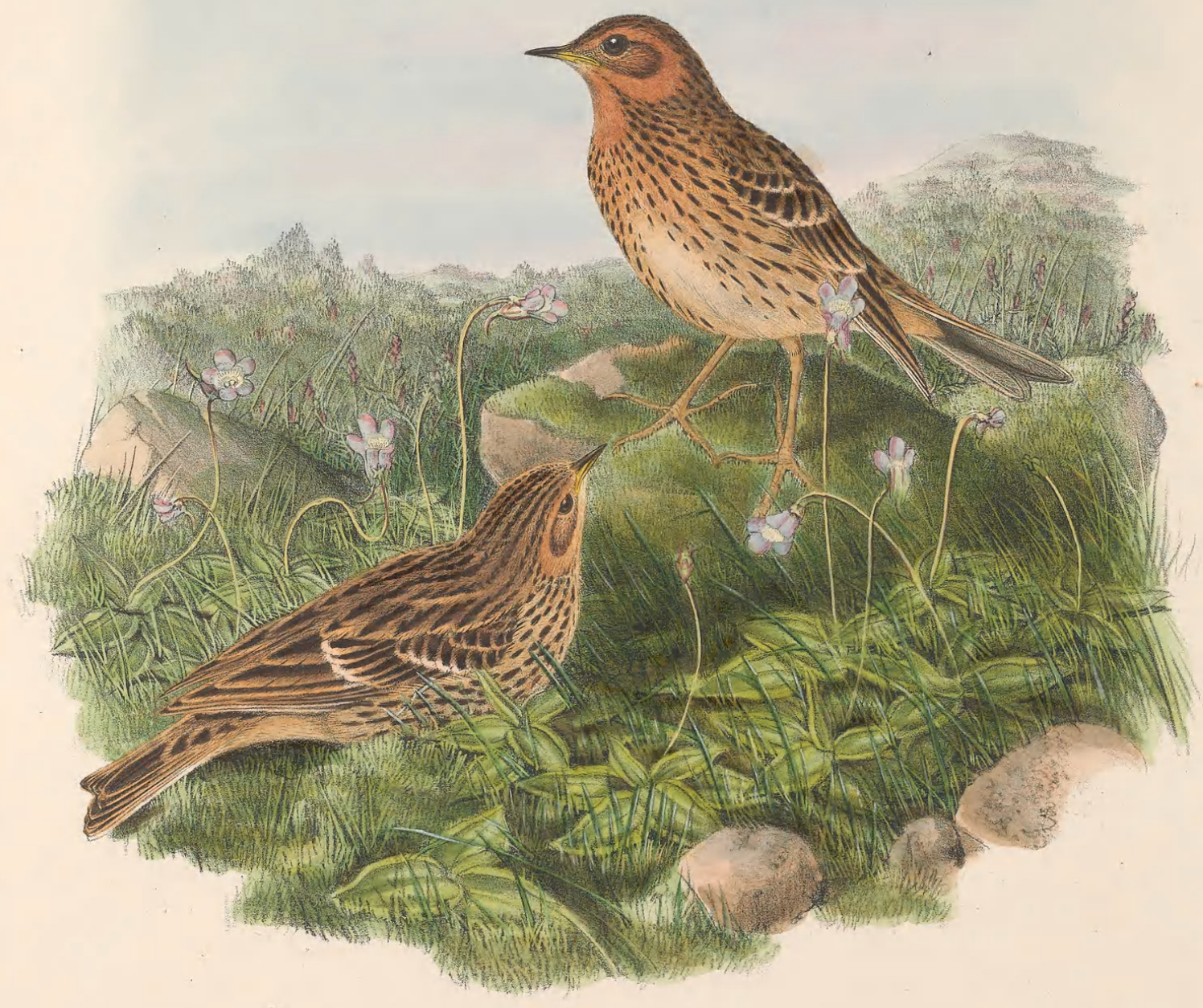




\section{ANTHUS CERVINUS.}

\section{Red-throated Pipit.}

Motacilla cervina, Pall. Zoog. Rosso-Asiat., tom. i. p. 511

Alauda Cacilii, Aud. Hist. de l'Egypte, Ois. tab. v. fig. 6.

Anthus rufogularis, Brehm, Lehrb., vol. ii. p. 963.

Cecili, Blyth, Cat. of Birds in Mus. Asiat. Soc. Calcutta, p. 324.

cervinus, Keys. et Blas. Wirb. Eur., p. 172.

pratensis rufigularis, Schleg. Rev. Crit. des Ois. d'Eur., p. xxxvi.

I FIGURE this very distinct species of Pipit in the 'Birds of Great Britain' on the authority of one of our most experienced and enthusiastic ornithologists, Mr. Harting-who states in his recently published 'Handbook of British Birds' that an example had been killed at Unst, in Shetland, on May 4, 1854 (and recorded by him in the 'Field' for August 26, 1871), and mentions that another was taken in September of the same year near Freshwater, in the Isle of Wight. These occurrences need not occasion surprise, since it is highly probable that a bird which is frequently found breeding in many parts of Scandinavia should at one season or another casually visit Britain. To many of our ornithologists it is unknown except by name ; and hence frequent mistakes as to its synonymy have been made. By some writers, both at home and abroad, it has been regarded as a variety of our ordinary Pipit (Anthus pratensis); from that bird, however, it differs in many particulars, the most conspicuous of which are its deep vinaceous colouring and the much more decided spotting of its back, characters distinguishing it from every other species of the genus.

As I have no additional information to communicate respecting this Pipit beyond that given in my 'Birds of Asia' from the writings of Professor Newton, Dr. Bree, and others, I am necessitated to repeat here much of what I have there recorded.

With regard to the synonymy, Professor Newton, in a letter to me, says, "The right name to be used for this species is a point on which I cannot exactly satisfy myself. Brehm's rufogularis appeared in his 'Lehrbuch' (vol. ii. p. 963) in 1824, while Pallas's cervina was only published in 1831 (Zoogr. Rosso-Asiat., vol. i. p. 511), though it had been in type since 1811. But I suspect the Anthus Ceecilii of Audouin to be the same species; and if so, I imagine that name will have unquestionable priority. I have not, however, been able to refer to the letterpress of the 'Description de l'Egypte' to see if the bird is therein properly described."

Professor Newton, however, in his interesting account of the discovery of the breeding bird, published in Dr. Bree's 'History of the Birds of Europe not found in the British Isles' (vol. ii. p. 155), uses Pallas's name of cervina; and so also do Bonaparte, Dr. Blasius, Dr. Bree, Mr. G. R. Gray, and Dr. Cabanis; while Dr. Schlegel and others either regard the bird as identical with $A$. pratensis, as a variety of that species, or adopt Pastor Brehm's name of rufogularis.

I cannot agree with Dr. Bree that it "belongs to the Rock-Pipit branch of the family, its claws being much curved," and that "there has been much confusion about the bird in consequence of this fact being overlooked ;" in fact it is as slender in form, and as delicate in the structure of its legs and hind toe as our own Titlark, and, moreover, has the hinder claw of the same lengthened and slender form as in that bird.

With regard to the parts of the Old World inhabited by this species, the testimony of those who have observed it in a state of nature gives Eastern Europe in winter, and Lapland, Finmark, Northern Russia, and Siberia as the countries frequented by it in summer, in all of which it probably breeds. That it also frequents the Crimea at the same season is certain, since I have seen specimens which were obtained there at that period of the year.

Dr. Bree, after remarking that the bird is found plentifully in Egypt, Nubia, Greece, Turkey, and Barbary during the winter, says, "I have been favoured with the following interesting account of its discovery in East Finmark by Alfred Newton, Esq. :"- " On the 22nd of June, 1855, a few days after our arrival at Wadso, Mr. W. H. Simpson and I, in the course of a bird's-nesting walk to the north-east of the town, to the distance perhaps of a couple of English miles, came upon a bog, the appearance of which held out greater promise to our ornithological appetites than we had hitherto met with in Norway. We had crossed the meadows near the houses, where Temminck's Stint and the Shore-Lark were trilling out their glad notes, and were traversing a low ridge of barren moor, when the solicitude of a pair of Golden Plovers plainly told us that their eggs or young were near us. . . . . A little while after, as I was cautiously picking my way over the treacherous ground, I saw a pipit dart out from beneath my feet, and alight again close by, in a manner that I was sure could only be that of a sitting hen. I had but to step off the grass-grown hillock on which I was standing, to see the 
nest ensconced in a little nook, half covered by herbage. But the appearance of the eggs took me by surprise ; for they were unlike any I knew-of a brown colour, indeed, but of a brown so warm that I could only liken it to that of old mahogany-wood, and compare them, in my mind, with those of the Lapland Bunting. However, there was the bird, running about so close to me that, with my glass, I could see her almost as well as if she had been in my hand. I replaced the eggs without disturbing the nest, and, carefully marking the spot, we retired. In half an hour or so we returned, going softly to the place; and Mr. Simpson, reaching his arm over the protecting hassock of grass, dexterously secured the bird in his hand as she was taking flight. I then at once knew, from her pale fawn-coloured throat, that the nest we had found belonged to a species which, up to that time, I believe had been known in Europe only as an accidental visitant.

"In a week's time we were quartered at Nyborg, a small settlement at the head of the Waranger Fjord. Here willows and birches grew with far greater luxuriance, even at the water's edge, than lower down the inlet. Some even attained to nearly twice the height of a man, and formed thickets which, the intervening spaces being exceedingly boggy, were not easily explored. In this secluded spot we found our red-throated friend not unplentiful. We could scarcely go out of the house without seeing one; and in the immediate neighbourhood we procured some more identified nests, making a total of five, and a fine series of nine birds, all of course in their breeding-plumage. We had also abundant opportunities of watching their habits, and, above all, of contrasting them with those of the Titlark (A. pratensis), which was not uncommon in the district, and to which this species has been so unjustly annexed as a variety. The two birds had, according to our observation, an entirely different range, $A$. pratensis haunting a station less wooded (saving the expression) than that of $A$. cervinus, which latter we found at times feeding on the sea-shore, a habit we did not notice the former to indulge in. No one with ears, either, could for a moment be in doubt about their respective notes. It is true that the full song of $A$. cervinus did not differ so strikingly from the more feeble performance of $A$. pratensis as does, for instance, the joyous burst of $A$. arboreus; but it had an unmistakable resemblance to the louder and perhaps harsher strains of $A$. obscurus, and in all cases was sufficiently characteristic for one to be quite certain as to the nature of the performer, even when the individual was not in sight. In a word, none of our party had any hesitation as to regarding A. cervinus as a perfectly good species.

"A young bird was obtained at Mortensnæs, between Wadso and Nyborg, on the 16th of July; and as it was attended by its parents (both of which were well seen by Mr. Wolley and myself), it could only have just left the nest; it appeared to differ from the young of the Titlark merely in being of a ruddier complexion. . . . . I have already mentioned what the eggs looked like; and it would be difficult, in words, to convey a better idea of them. All the nests I saw were simply built of dry bents, without any lining of feathers or hair."

Middendorff, who considers A. rufogularis and A. cervinus to be identical, says of the latter, "This bird was found in both North and South Siberia. I shot a female in the Stanowoj mountains, on the 26th of May, consequently not on the passage. The rust-yellow of the Siberian specimen has a somewhat violet tint, very similar to the colour on the breast of the Turtle Dove; it covers the cheeks near the eyes, the breast, flanks, neck, and upper part of the breast. It is only found in this plumage from May to July."

The Rev. H. B. Tristram obtained a single specimen only on the coast of the plain of Sharon in winter -that is, in the month of February.

Mr. Swinhoe states that it is "a winter bird in South China and Formosa, which passes the summer in Kamtschatka and the northern regions. Flocks pass over Amoy as late as the first week in May. Before leaving China the bird undergoes an entire moult, when the eyebrows, throat, and breast show a pale vinaceous mixed with more or less ochreous, but unspotted. As the nuptial season comes on, the silvery tinge intensifies into a uniform dusky vinaceous, which encroaches further on the lower parts. I have a fine series, showing every gradation between the pale-spotted winter and the fine nuptial dress."

The male has the head, neck, back, rump, and upper tail-coverts olive, with a broad stripe of dark brown down the centre of each feather, even on those of the rump ; wing-coverts dark brown, tipped with creamy white; primaries brown, with paler edges; tertiaries very dark brown, bordered with light greyish brown; tail brown, the two centre feathers edged with tawny, and the other part white, with a streak of brown down the margin of the inner web; the next with a triangular spot of white at the tip; throat, cheeks, and breast rufous, with a gorget formed by longitudinal streaks of brown across the latter; abdomen and under tailcoverts pale fawn-colour, streaked on the flanks with dark brown.

In the female the rufous colouring is confined to the throat and cheeks, and the breast is more thickly streaked with dark brown; in other respects the plumage resembles that of the male.

The figures, which are of the natural size, represent two states of plumage. The plant is the Pinguicula vulgaris. 


\section{$2 \mathrm{BHL}$ Biodiversity Heritage Library}

Gould, John. 1873. "Red-throated Pipit, Anthus cervinus [PI. 12]." The birds of Great Britain 3, -. https://doi.org/10.5962/p.323903.

View This Item Online: https://www.biodiversitylibrary.org/item/221726

DOI: https://doi.org/10.5962/p.323903

Permalink: https://www.biodiversitylibrary.org/partpdf/323903

\section{Holding Institution}

Smithsonian Libraries

\section{Sponsored by}

Biodiversity Heritage Library

\section{Copyright \& Reuse}

Copyright Status: Public domain. The BHL considers that this work is no longer under copyright protection.

This document was created from content at the Biodiversity Heritage Library, the world's largest open access digital library for biodiversity literature and archives. Visit BHL at https://www.biodiversitylibrary.org. 